\title{
Holistic Mentoring through Sharing an Entire Course Built on the ExCEEd Model
}

\section{Dr. Ronald W. Welch, The Citadel}

Ron Welch (P.E.) received his B.S. degree in Engineering Mechanics from the United States Military Academy in 1982. He received his M.S. and Ph.D. degrees in Civil Engineering from the University of Illinois, Champaign-Urbana in 1990 and 1999, respectively. He became the Dean of Engineering at The Citadel on 1 July 2011. Prior to his current position, he was the Department Head of Civil Engineering at The University of Texas at Tyler from Jan 2007 to June 2011 as well as served in the Corps of Engineers for over 24 years including eleven years on the faculty at the United States Military Academy.

\section{Dr. Timothy W Mays P.E., The Citadel}

Timothy Wayne Mays, Ph.D., P.E. is a Professor of Civil Engineering at The Citadel in Charleston, SC. Dr. Mays recently served as Executive Director of the Structural Engineers Associations of South Carolina and North Carolina. He currently serves as NCSEA Publications Committee Chairman. He has received three national teaching awards (ASCE, NSPE, and NCSEA) and both national (NSF) and regional (ASEE) awards for outstanding research. He is the recipient of the 2009 NCSEA Service Award. His areas of expertise are code applications, structural design, seismic design, steel connections, structural dynamics, and civil engineering aspects of antiterrorism.

\section{Dr. Monika Bubacz, The Citadel}

Dr. Monika Bubacz is an Associate Professor in the Department of Engineering Leadership and Program Management at The Citadel. She received both her B.S. and M.S. in Mechanical Engineering from Poznan University of Technology in Poland, and the Ph.D. in Engineering and Applied Science from the University of New Orleans. Before her current appointment she has worked for Mercer University, Center for NanoComposites and Multifunctional Materials in Pittsburg, Kansas and Metal Forming Institute in Poznan, Poland. Her teaching and research interest areas include materials science, polymers and composites for aerospace applications, nanotechnology, and environmental sustainability.

\section{Kevin Skenes, The Citadel}

Kevin Skenes is an assistant professor at The Citadel. His research interests include non-destructive evaluation, photoelasticity, manufacturing processes, and engineering education.

\section{Mrs. Kaitlin Marley, University of California - San Diego}

Kaitlin Marley is a doctoral student at the University of California-San Diego in the Structural Engineering Department. She earned her Bachelor of Science degree in Civil Engineering from North Carolina State University in 2008, and her Master of Science degree in Geotechnical Engineering from the University of California-Berkeley in 2009. She worked as full-time lecturer in the Department of Civil and Environmental Engineering at The Citadel in Charleston, SC, from the fall of 2010 through the fall of 2013.

\section{Dr. James Michael Grayson, The Citadel}

Dr. J. Michael Grayson is a former National Science Foundation Graduate Research Fellow at Clemson University where he received the Bachelor of Science in Civil Engineering (BSCE) with a minor in Environmental Engineering (summa cum laude) followed by the Master of Science in Civil Engineering (MSCE) and PhD both with an emphasis in structural engineering. Dr. Grayson has extensive experience in the structural framing and finishing of light-frame commercial and residential buildings, as well as experience in bridge and highway construction and inspection practices with the South Carolina Department of Transportation (SCDOT). A native of Okatie, SC, firsthand experience of the devastation left in the wake of Hurricane Hugo (1989) continues to have a profound influence on Dr. Grayson's teaching 
and research accomplishments and goals at The Citadel. Dr. Grayson continuously strives to improve his teaching in the classroom in order to produce principled civil and environmental engineering leaders that are capable of thinking critically about topics while fostering a lifelong love and capacity for independent learning. 


\title{
Holistic Mentoring Through Sharing an Entire Course Built on the ExCEEd Model
}

\begin{abstract}
Faculty mentoring is a process/activity that can occur early, mid-career, or even when administrators are returning to a teaching role. Mentoring can take on numerous forms to include classroom observation, discussions on content within a course, philosophical discussion over what content to include and how it can be best delivered, formal/informal review of course content, review of individual lesson notes, sharing a syllabus and text, and the sharing of lesson notes, homework, exams, design problems, and study guides or any portion of the aforementioned. However, what type of mentoring is the most effective at rapidly improving the quality of instruction? This paper presents the results of one faculty member completing a combination of the above as a form of holistic mentoring (using multiple mentoring processes, but especially the use of sharing an entire course) with two new faculty members, a lecturer, and two mid-term faculty members. The analysis examines student assessments and faculty reflections on the mentoring process and how it greatly improved their current methods to prepare and then teach follow-on courses. This paper will highlight that the demonstration of teaching techniques from the ASCE ExCEEd Teaching Model to new instructors while teaching a course can rapidly change the quality of faculty instruction.
\end{abstract}

\section{Introduction}

As new educators join a faculty team with freshly minted doctoral degrees, many toil through trial and error experiences as they trudge toward meeting tenure and then post tenure expectations in teaching, scholarship, and service. The perception is that the research completed during the degree granting process and personal connections set each faculty member up for continued successful research, while observations and opportunities filling in for an advisor prepares each for the teaching role. However, there are numerous faculty who initially fail to meet expectations without additional mentoring and/or training to actualize desired performance levels.

The number of grant writing and teaching workshops has multiplied in recent years to answer the call for more training. ${ }^{1}$ These workshops greatly enhance the ability of department leadership to provide the necessary support for new faculty as well as improve the performance of tenured faculty. However, there is not always time to send each and every faculty member to the appropriate workshop. Resources, research schedules, limited workshop seats, and other personal priorities versus the desires of the academic leadership also complicate timely training. This paper focuses on an alternate approach to preparing faculty to be first competent, and hopefully exceptional, teachers.

One of the authors has been a longtime mentor, content provider, and workshop coordinator for the 6-day ASCE ExCEEd (Excellence in Civil Engineering Education) Teaching Workshop. However, the limited number of workshop seats and the (very reasonable) policy to ensure that the available seats impact as many universities as possible can severely limit the ability as an academic leader to make rapid change within an academic unit's teaching dimension. Therefore, 
other courses of action are sometimes needed to influence more faculty in a shorter time frame. The hope upon arrival at the new school for this long-time ExCEEd mentor and content provider was to require all faculty to attend a 2-day mini-ExCEEd at the beginning of the spring semester. This seems reasonable since every teacher can improve, but the senior leaders (department heads and full professors) felt that their high US News and World Report ranking pointed to their success as teachers and that they did not need the new academic leader requiring something that would basically say he did not think they were good teachers. Obviously an alternate approach was required: an optional bi-weekly presentation/discussion of the ExCEEd Teaching Workshop seminars. However, only sixty percent of the faculty attended approximately fifty percent of the presentations. None opted for peers to sit in their classes to provide feedback on the implementation of new concepts learned from the seminars. So impact was very limited.

The last three years have seen significant change in faculty with nine new faculty being hired. Each was required to attend a mini-ExCEEd workshop (by cohort) prior to their spring semester (which allowed for the use of fall semester experiences to inform discussions). However, time available to expand the experience to include each new faculty member teaching multiple classes in front of peers and receiving assessment from all participants was impossible because of spring teaching schedules and summer research/teaching schedules. Occasional individual assessment opportunities between individual cohort members have been possible, but most observation and teaching mentorship has been limited to department heads and senior faculty (who did not attend or did not attend all of the seminars mentioned above) as part of the tenure process. However, a rarely used practice in some department cultures of full sharing of intellectual property (including course documents, exams, homework, course schedule, and most importantly lesson notes) has resulted in very interesting and promising results that are being presented, analyzed and discussed in this paper.

One of the authors has shared all parts of his ASCE ExCEEd Teaching Model built course, especially his minimized lesson board notes with administrative notes which include physical models and demonstrations, areas to emphasize, etc. with a wide range of faculty (lecturer, nontenured tenure-track assistant professors, and associate professors) who also teach the course. The course, Mechanics of Materials, focuses on the performance of structures and members based on stress and deformations calculations. Additionally this same author has taught the course during the same semester as three of the other authors and provided mentorship when requested (varied) with some of the other authors, and at other times just provided the course material, but still was available to mentor when approached.

This paper presents the conditions for each faculty member, the assessment results of the semester using the provided content compared to previous and post semesters and courses, analysis of student comments and specific surveys associated with this project, and faculty reflection on the semester they used the ExCEEd Teaching Model built course notes as well as the impact it has had on their teaching. The data will show that each faculty member experienced an improvement within their student assessments and comments during that semester and subsequent semesters. 


\section{The ASCE ExCEEd Teaching Model}

The ASCE ExCEEd Teaching Model (Figure 1) is largely based on the 40 year teaching training model at the United States Military Academy, West Point, for new Civil and Mechanical Engineering faculty and closely resembles a compilation of best practices from literature on student learning. ${ }^{2-8}$ The combining of the ExCEEd Teaching Model with a model instructional strategy (Figure 2) results in a lesson (course) that provides the minimum structure that a student needs to learn and the type of teacher performance that many students require to achieve excellence.

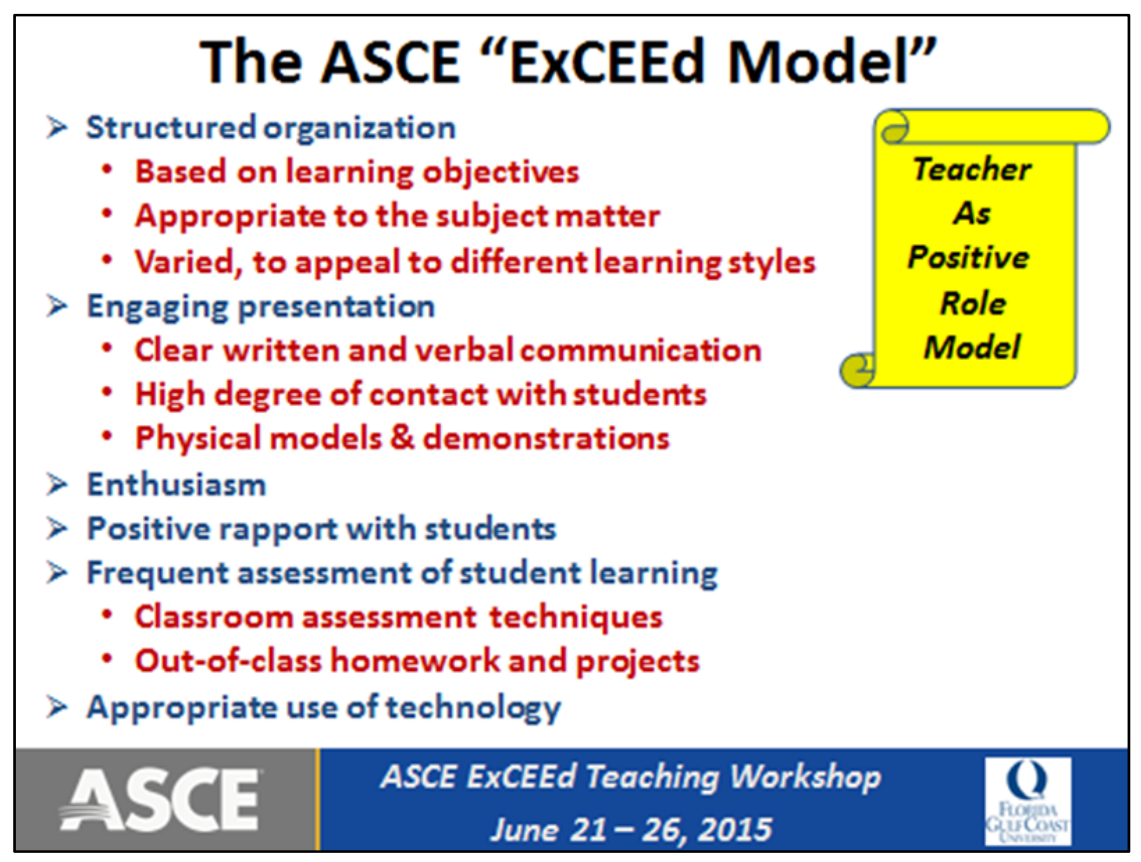

Figure 1. The ASCE ExCEEd Teaching Model

These two figures are the foundation for the ExCEEd Teaching Workshop where the skills and techniques necessary to fulfill meeting the expectations inherent in these models are presented, discussed, and practiced. The typical ASCE ExCEEd Teaching Workshop (ETW) schedule for the six-day workshop is shown in Figure 3 and is representative of the workshop at different sites (United States Military Academy, University of Arkansas, University of Northern Arizona, University of Texas at Tyler, and Florida Gulf Coast University). The workshop activities can be sub-classified into seminars, demonstration classes, laboratory exercises, and social events. ${ }^{1}$

Seminars: The primary course schedule for the ETW contains 13 Seminars which vary in content and were designed to provide theoretical background, teaching hints, organizational structure, and communication techniques. All 24 participants (6 teams) are together but sit with their team members. A brief description of each seminar is offered in Table 1. The seminars are presentations given by senior ETW faculty and include small group activities and facilitated collaborative discussions. The seminars may vary slightly from year to year and site to site as the workshop always experiments with new content. Additional seminars not shown in Table 1 have 
included Creating a Syllabus, Group Projects, Managing Student Teams, Active Learning, Gender and Diversity, and Teaching with Technology.

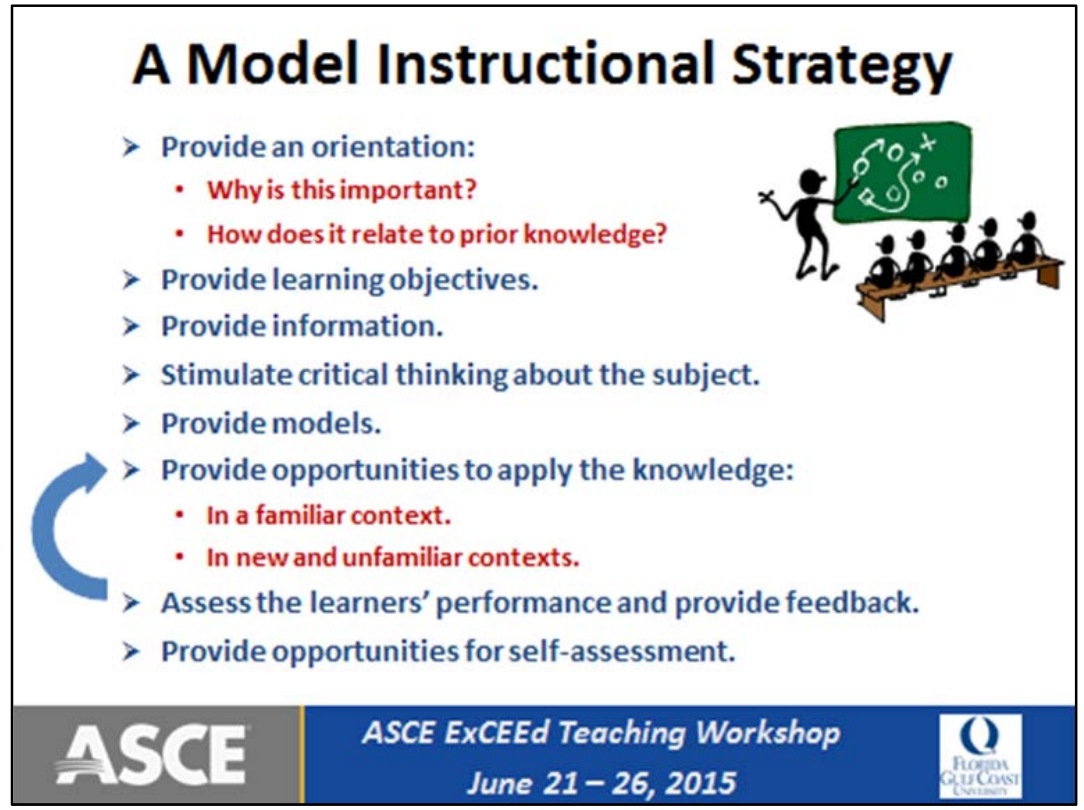

Figure 2. A Model Instructional Strategy

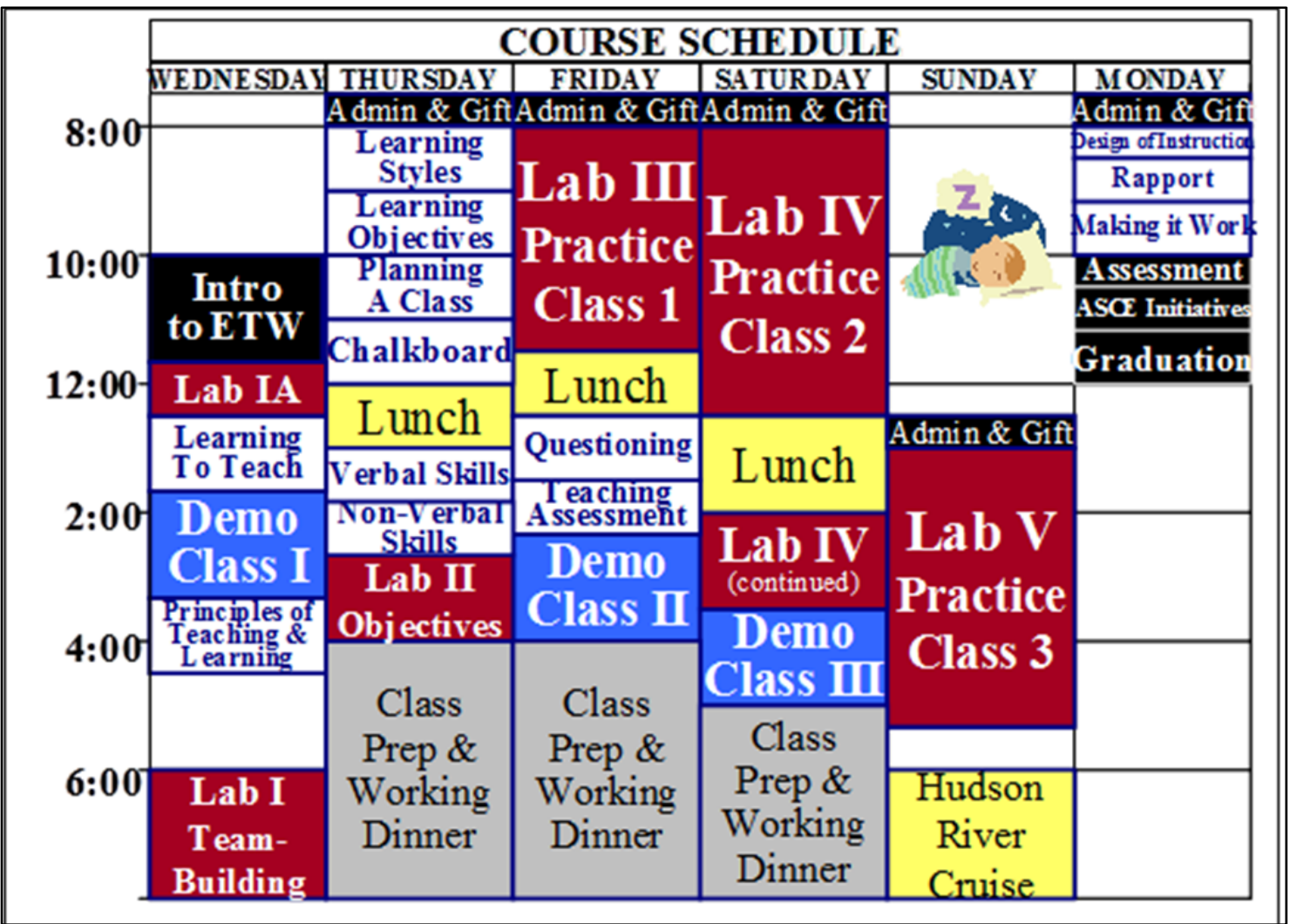

Figure 3. ExCEEd Course Schedule for a typical ExCEEd Teaching Workshop 
Demonstration Classes: ExCEEd faculty members teach example engineering classes where the workshop participants are role-playing as students. These demonstration classes are intended to role model exemplary teaching, to illustrate active engagement with students, and to reinforce the methods of teaching covered in the seminars in a realistic classroom environment. Demonstration classes are deliberately spaced at intervals throughout the workshops so that participants can better observe and appreciate different aspects of teaching as the workshop progresses. Afterward, the participants formally assess the class strengths and areas for improvement.

Table 1. Content of the ExCEEd Teaching Workshop Seminars

\begin{tabular}{|l|l|}
\hline \multicolumn{1}{|c|}{ ExCEEd Teaching Workshop Seminars } \\
\hline I & $\begin{array}{l}\text { Learning to Teach: Justifies importance of formally learning to teach and } \\
\text { introduces a model instructional strategy that will be a road map for the ETW }\end{array}$ \\
\hline II & $\begin{array}{l}\text { Principles of Effective Teaching and Learning: Introduces Lowman's (1995) } \\
\text { two-dimensional model of teaching and provides a compendium of learning } \\
\text { principles which together form the ExCEEd Teaching Model }\end{array}$ \\
\hline III & $\begin{array}{l}\text { Introduction to Learning Styles: Introduces Felder's (1993) Learning Style } \\
\text { Dimensions and examines how to accommodate all styles of learners }\end{array}$ \\
\hline IV & $\begin{array}{l}\text { Learning Objectives: Introduces Bloom's (1956) taxonomy of educational } \\
\text { objectives and demonstrates how to write appropriate and useful learning } \\
\text { objectives }\end{array}$ \\
\hline V & $\begin{array}{l}\text { Planning a Class: Offers a structured methodology for organizing a class with } \\
\text { emphasis on constructing an outline, board notes, and out-of-class activities }\end{array}$ \\
\hline VI & $\begin{array}{l}\text { Writing: Covers the fundamentals of making written presentations using the } \\
\text { chalk board, vu-graphs, and PowerPoint slides }\end{array}$ \\
\hline VII & $\begin{array}{l}\text { Teaching Assessment: Covers student, peer and self-assessments and separates } \\
\text { myth from fact regarding their usefulness. Classroom assessment techniques } \\
\text { (Angelo and Cross, 1993) are illustrated throughout the seminars. }\end{array}$ \\
\hline VIII & $\begin{array}{l}\text { Communications - Speaking: Covers fundamentals of communication skills with } \\
\text { emphasis on speaking to a group and generating positive emotion from students }\end{array}$ \\
\hline IX & $\begin{array}{l}\text { Communications - Questioning: Examines different student questioning } \\
\text { techniques and discusses effective strategies for their use }\end{array}$ \\
\hline X & $\begin{array}{l}\text { Systematic Design of Instruction: Introduces a model for designing a new course } \\
\text { in an established curriculum and examines the role of classroom teaching in that } \\
\text { model }\end{array}$ \\
\hline XIII & $\begin{array}{l}\text { Non-Verbal Communication: Offers useful insights and techniques for } \\
\text { non-verbal cues from students. } \\
\text { effective rapport with students; discusses student personality types and offers hints } \\
\text { to avoid chill in the classroom } \\
\text { principles covered at ETW can be incorporated under conditions that exist at other } \\
\text { institutions such as larger class sizes, no blackboards, etc. }\end{array}$ \\
\hline
\end{tabular}


Laboratory Exercises: The participants spend close to half of their ETW time in small group laboratory assignments. A team consists of four workshop participants, a junior mentor (usually a recent graduate of ETW) and a senior mentor (a veteran instructor with many years of successful teaching experience who is also well-versed in the methods of ETW). Each participant teaches three classes (25 minutes, 50 minutes, and 25 minutes, respectively) in his or her area of expertise while the other members of the group role-play as students. Afterward, each class is assessed. Initially the critiques are provided by the senior mentor, but as the workshop progresses, the fellow participants provide the assessments. Ultimately, the participant who taught the class provides a self-assessment. Each participant receives written assessments and video recordings of his or her classes.

Team Building and Social Events: While much of the evening time is spent preparing for the teaching laboratories, ETW also includes social events to promote team-building, collaboration and the sharing of ideas. A key element to the success of the laboratory exercises and the overall workshop is the need for participants to become comfortable with each other and to form wellfunctioning teams. Team-building is fostered early in the workshop through an introductory banquet or picnic (depending on site and weather) with competitive team activities. The mentors also use meals and morning / afternoon snack breaks for team building, reflection time, and discussion. A closing dinner provides participants with an opportunity to interact with others outside of their own teams and to celebrate their achievements after four days of hard work.

Mini-ExCEEd Teaching Workshops: A Mini-ExCEEd Teaching workshop is a two-day workshop that focuses on presenting two demonstration classes by master teachers and 9-10 seminars (normally Seminars 1-9, 11, Table 1, occasionally Seminar VII is minimized to only the assessment form presented before demonstration class 2). As can be seen in the typical ExCEEd Teaching Workshop schedule (Figure 3), the laboratory exercises, team building, and social events are normally absent due to time constraints. A mini-ExCEEd is designed to provide content at a location where the participants know each other, there are a number of recent ETW graduates or ETW junior/senior mentors available to mentor their colleagues, participants are likely to form cohorts to observe each other's classes and provide assessment, and/or to encourage participants to attend the full six-day workshop. Mentors and assistant mentors at the six-day workshop continually comment on learning something new each time they experience the seminars, so participant attendance at the weeklong ExCEEd Teaching Workshop after a mini-ExCEEd further enhances the assembly of knowledge and understanding of key concepts especially through the practice classes.

Only the lead author has been involved with a six-day ExCEEd workshop; all others have either attended some of the seminars as part of seminars presented over an entire semester or all of the seminars and a demonstration class as part of a mini-ExCEEd (two-day) workshop before the spring semester.

\section{Mechanics of Materials}

Mechanics of Materials is a required course in most Civil and Mechanical Engineering programs. The course follows Statics and moves analysis beyond "rigid bodies" to "deformable bodies" to include discussion of stresses and deformation resulting in determination of member/material 
performance. The course is typically the first focused effort to teach/learn design principles using allowable stress design. Table 2 shows the sequence and list of topics covered in this version of the course during the Spring 2016 semester. Only the dates have changed except for the summer offering by one faculty member where multiple lessons were covered during a single day since the summer semester is only 5 weeks long.

Table 2: CIVL 304 Mechanics of Materials course schedule

\begin{tabular}{|c|c|c|c|}
\hline & & & CIVL 304 Mechanics of Materials Spring 2016 \\
\hline Lsn & $\begin{array}{l}\text { Study } \\
\text { Notes }\end{array}$ & Date & Lesson Title \\
\hline 1 & MM-1 & 14-Jan & Intro, Internal Forces, Normal/Shear Stress \\
\hline \multirow[t]{2}{*}{2} & MM-2 & 19-Jan & Stress, Introduction to design \\
\hline & & 19-Jan & Add Drop Ends \\
\hline 3 & MM-3 & 21-Jan & Strain, Mechanical Properties of Materials \\
\hline \multirow[t]{2}{*}{4} & MM-4 & 26-Jan & $\begin{array}{l}\text { Mechanical Properties of Materials/ Stress } \\
\text { Transformation }\end{array}$ \\
\hline & & 27-Jan & Audit or Pass/Fail \\
\hline 5 & MM-5 & 28-Jan & Stress Transformation (Mohr's Circle) \\
\hline 6 & MM-6 & 2-Feb & Strain Transformation \\
\hline 7 & MM-7 & 4-Feb & Strain Trans/ Thin Walled Pressure Vessels \\
\hline 8 & MM-8 & 9-Feb & Working Session \\
\hline 9 & MM-9 & 11-Feb & Exam 1, Fatigue \\
\hline 10 & MM-10 & 16-Feb & Axial Deformation \\
\hline 11 & MM-11 & 18-Feb & Axial Deformation/ Stress Concentrations \\
\hline 12 & MM-12 & 23-Feb & Elastic Torsion \\
\hline 13 & MM-13 & 25-Feb & Elastic/Inelastic Torsion \\
\hline 14 & MM-14 & 1-Mar & Theories of Failure \\
\hline 15 & MM-15 & 3-Mar & Statically Indeterminate Torsion members \\
\hline 16 & MM-16 & 6-Mar & Combined Loading /Working Session \\
\hline 17 & MM-17 & 10-Mar & Exam 2, Shear and Moment Diagrams \\
\hline \multirow[t]{2}{*}{18} & MM-18 & 15-Mar & Shear and Moment Diagrams \\
\hline & & 16-Mar & Last date to Withdraw/Election Day \\
\hline 19 & MM-19 & 17-Mar & Elastic Bending I \\
\hline 20 & MM-20 & 22-Mar & Elastic/Inelastic Bending by Equilibrium \\
\hline 21 & MM-21 & 24-Mar & Transverse Shear Stress \\
\hline 22 & MM-22 & 5-Apr & Design of Prismatic Beams I \\
\hline 23 & MM-23 & 7-Apr & Design/ Introduction to Beam Deflections \\
\hline 24 & MM-24 & 12-Apr & $\begin{array}{l}\text { Beam Deflections by Discontinuity Functions and } \\
\text { Superposition }\end{array}$ \\
\hline 25 & MM-25 & 14-Apr & Column Buckling \\
\hline 26 & MM-26 & 19-Apr & Working Session/Course Assessment \\
\hline 27 & MM-27 & 21-Apr & Exam 3, Column Buckling \\
\hline \multirow[t]{2}{*}{28} & MM-28 & 26-Apr & Combined Loading /Summary \\
\hline & Sec 02 & Tues 3-May & Final Exam 1 pm - 4 pm \\
\hline
\end{tabular}


The course consists of 3 mid-term exams and a comprehensive exam as well as daily homework and three design problems. The basic structure, sequence, study guide (each lesson outlined with lesson objectives, reading assignment, additional notes beyond the textbook reading assignment, home study problems that are not homework but additional practice with solutions posted to Blackboard, in-class problem sheets focused on key topics each lesson), and final exam were used by each faculty member in this paper.

Course structure begins with course outcomes that result in individual lesson objectives that support the course outcomes. An orientation as to why today's content is important helps reduce content to the absolute minimum and help students connect the dots between the textbook theory and application shown in class examples. Content is enhanced through enthusiastic, passionate written, verbal, and graphical (pictures, free body diagrams, physical models and demonstrations, use of technology) communication that appeals to varied learning styles: active vs. reflective, sensory vs. intuitive, visual vs. verbal, and sequential vs. global. Using students' names when asking thought provoking questions engages each in personalized scaffolding of course content while also assisting in the development of positive rapport between the student and the teacher. Throughout the semester the teacher is assessing student learning through in-class assessment techniques and out-of-class homework (daily homework in this course) and projects.

\section{Participants within the study}

Dr. Ron Welch, principal mentor, Full professor, previous Department Head, PhD CE, 40 semesters teaching, taught statics one semester, statics-dynamics one semester, mechanics of materials 11 semesters, statics and mechanics of materials 1 semester, and numerous other CE courses.

Dr. Monika Bubacz, associate professor, PhD ME, taught single course focused on Statics and 30 percent Mechanics of Materials for many semesters, taught Mechanics of Materials during summer 14 using the same content as others, 14th semester teaching, taught other ME courses in advanced materials and composites.

Dr. Kevin Skenes, tenure-track assistant professor, PhD ME, taught Mechanics of Materials, had all previous course materials, taught alone, never taught course before, second semester teaching, teaches other ME courses in manufacturing.

Dr. Tim Mays, associate professor (first semester co-teaching Mechanics of Materials) and then full professor one year later (second co-teaching semester), $\mathrm{PhD} \mathrm{CE}$, lead author wrote exams, $\mathrm{HW}$, started with the same board notes with adjustments for personal style, 2 semesters, never taught the course before, 23 and 25th semester teaching, teaching other CE structural courses to include dynamics.

Kaitlin Marley, instructor, MSCE, lead author wrote exams, HW, started with the same board notes with adjustments for personal style, never taught the course before, seventh semester teaching, course taught during Fall 2012. 
Dr. J. Michael Grayson, tenure-track assistant professor, PhD CE, lead author wrote exams, HW, started with the same board notes with adjustments for personal style, never taught the course before, second semester at this institution and 5th teaching, course taught during Spring 2016 with data to be added at the ASEE National conference.

\section{Faculty Data, Student Comments, and Reflection}

Kaitlin Marley, lecturer, currently serves as a doctoral student at the University of California-San Diego in geotechnical engineering. She worked as a full-time lecturer at The Citadel from the fall of 2010 through the fall of 2013. Prior to joining The Citadel, Kaitlin developed teaching experience at North Carolina State University working as a tutor and Supplemental Instruction leader for Calculus I and II, Engineering Mechanics - Statics, and Engineering Mechanics Dynamics from 2005 to 2008. During her time at The Citadel, Kaitlin taught twelve different courses and laboratories including CIVL 202, CIVL 210, CIVL 301, CIVL 304, CIVL 314, and CIVL 320. As a lecturer, Kaitlin developed her teaching skills initially while working with senior faculty. She also participated in the ASCE ExCEEd mini-workshop offered at The Citadel prior to the spring of 2013. These experiences served as the basis for her own teaching style and philosophy which she implemented in a variety of subsequent courses.

Prior to the fall of 2012, the semester Kaitlin co-taught CIVL 304 with Dr. Welch, she had minimal exposure to the ExCEEd model. Additionally, she had not previously co-taught a course with a senior faculty member by presenting identical content, assignments, and tests. Therefore, the experience served as her first exposure to the ExCEEd model style, completely coordinated co-teaching, and deliberate senior faculty mentoring. The co-teaching team met weekly to discuss the next week's content, why it was taught in the provided order by Dr. Welch, and how to best use physical models and questioning techniques to effectively enhance content presentation. Following her experience with CIVL 304 and concurrent participation in the ASCE ExCEEd mini-workshop, Kaitlin strove to re-focus CIVL 202, CIVL 210, and CIVL 301 in spring, summer, and fall of 2013 before leaving The Citadel to obtain her doctorate (senior leader mentoring motivated her to seek a PhD). Focusing on her personal areas for improvement, she specifically began to:

- provide clear, focused learning objectives to students every lecture,

- develop and retain an irreducible minimal set of color-coded board notes,

- include a corresponding homework assignment for every lecture due the following class period,

- deliberately incorporate content appealing to a variety of learning styles, and

- generally increase the use of physical models in lectures.

Table 3 contains a summary of Kaitlin Marley's teaching evaluations for each semester taught at The Citadel. Laboratory courses have been omitted in order to focus on lecture courses that receive the greatest impact from experienced mentoring and the ExCEEd model. Table 4 contains a summary of Kaitlin's teaching evaluations by specific question separated into before formal mentoring and introduction to the ExCEEd model (prior to the fall of 2012) and after formal mentoring and familiarization with the ExCEEd model (the fall of 2012 and beyond). 
Examination of Table 4 reveals improvement in nearly every category. Clearly, implementation of the new teaching strategies affected students positively. Two of the questions that degraded, questions 6 and 7, discuss the faculty member's effective use of time. One of the challenges in presenting pre-determined content within an allotted amount of time is ensuring that all content is completely covered. This proved to be the most difficult aspect of implementation of coteaching multiple sections for Kaitlin, and she struggled to cover all required material without class exceeding the designated class period. If Kaitlin had continued to be a lecturer at The Citadel, she would certainly have continued to improve in this area. Question 10 also slightly dropped. This effect can most likely be attributed to the implementation of a new, difficult lifelong learning module in CIVL 210 during the fall of 2013 that reduced overall feedback in that course, as shown in Table 3.

Table 3 - Comparison of faculty questions average score from course evaluations separated by each semester taught at The Citadel

\begin{tabular}{lll}
\hline Semester Since Started & Course & $\begin{array}{l}\text { Average Score } \\
\text { (1-5 Likert Scale) }\end{array}$ \\
\hline 1 (Fall 2010) & CIVL 320 & 4.8 \\
2 (Spring 2011) & CIVL 202 & 4.8 \\
3 (Summer 2011) & CIVL 301 & 4.6 \\
4 (Fall 2011) & CIVL 301 & 4.8 \\
5 (Spring 2012) & CIVL 202 & 5.0 \\
6 (Summer 2012) & CIVL 301 & 4.9 \\
7 (Fall 2012) & CIVL 210 & 4.8 \\
8 (Spring 2013) & CIVL 304 & 4.9 \\
9 (Summer 2013) & CIVL 202 & 4.9 \\
10 (Fall 2013) & CIVL 314 & 4.9 \\
\hline
\end{tabular}

Dr. Bubacz is an associate professor, Mechanical Engineering, who has taught engineering core courses before joining The Citadel. The course offered at the other institution was a combined Statics and Mechanics of Materials course typically taught twice a year for six and a half years (2006 - fall 2012). The courses taught at The Citadel based on this previous experience were: CIVL 202 Statics (SP14, F14, S15), CIVL 304 Mechanics of Materials (Su14) and CIVL 310 Statics and Strength of Materials for Non-Civil Engineers (SP14). CIVL 304 and 310 were taught only once, during evening and day respectively. CIVL 202 was taught multiple times with multiple sections during the day. The associate professor twice attended the ASCE ExCEEd mini-workshop offered at The Citadel - immediately after joining the school (before SP13) and one year later as a refresher (before SP14). 
Table 4 - Comparison of faculty questions score from course evaluations separated by before formal mentoring and introduction to the ExCEEd model (prior to the fall of 2012) and after formal mentoring and familiarization with the ExCEEd model (the fall of 2012 and beyond).

\begin{tabular}{lll}
\hline Question & $\begin{array}{l}\text { Score before } \\
\text { mentoring and } \\
\text { ExCEEd } \\
\text { (prior to fall 2012) }\end{array}$ & $\begin{array}{l}\text { Score after } \\
\text { mentoring and } \\
\text { ExCEEd } \\
\text { (fall 2012 and } \\
\text { beyond) }\end{array}$ \\
\hline 1. $\quad \begin{array}{l}\text { My professor displays a clear } \\
\text { understanding of course topics. }\end{array}$ & 4.8 & 4.9 \\
2. $\quad \begin{array}{l}\text { My professor seems well-prepared for } \\
\text { class. }\end{array}$ & 4.9 & 4.9 \\
3. $\quad$ My professor speaks audibly and clearly. & 4.9 & 5.0 \\
4. $\quad \begin{array}{l}\text { My professor displays enthusiasm when } \\
\text { teaching. }\end{array}$ & 4.9 & 5.9 \\
5. $\quad \begin{array}{l}\text { My professor makes good use of } \\
\text { examples and illustrations. }\end{array}$ & 4.8 & 4.9 \\
6. $\quad \begin{array}{l}\text { My professor makes effective use of } \\
\text { class time }\end{array}$ & 4.8 & 4.3 \\
7. $\quad \begin{array}{l}\text { My professor begins and ends class on } \\
\text { time. }\end{array}$ & 4.8 & 4.3 \\
8. $\quad \begin{array}{l}\text { My professor is readily available for } \\
\text { consultations. }\end{array}$ & 4.9 & 4.9 \\
9. $\begin{array}{l}\text { My professor effectively challenged me } \\
\text { to think. }\end{array}$ & 4.8 & 4.8 \\
10. $\begin{array}{l}\text { My professor communicated the subject } \\
\text { matter effectively. }\end{array}$ & 4.7 & 4.9 \\
11. $\begin{array}{l}\text { When I have a question or comment I } \\
\text { know it will be respected. }\end{array}$ & 4.9 & 4.9 \\
12. $\begin{array}{l}\text { I would recommend taking a course } \\
\text { taught by this professor. }\end{array}$ & 4.8 & 4.9 \\
13. I would enjoy taking another course \\
$\begin{array}{l}\text { from this professor. } \\
\text { 14. I would rate my professor as an } \\
\text { excellent teacher }\end{array}$ & 4.8 & 4.8 \\
\hline
\end{tabular}

CIVL 310 was taught using notes and resources from Dr. Welch; CIVL 304 was taught using modified notes and lecture schedule from Dr. Welch and closely following the textbook. Both courses were taught using a textbook Dr. Bubacz was familiar with. The first semester of CIVL 202 was taught without any notes or directions from previous instructors, only the catalog description. A textbook was assigned but Dr. Bubacz was not familiar with the author. Thus CIVL 202 Statics was built by Dr. Bubacz and strongly influenced by ExCEEd techniques. The 
course presentation can be divided between PowerPoint presentations and whiteboard examples in a ratio of 1:1. Before each exam, there were review sessions conducted completely on whiteboard.

The first attempt to include ExCEEd best practices occurred during the semester after the miniExCEEd workshop (SP13) and included board notes, handouts with lesson objectives, physical models, and a higher degree of contact with students: using students' first names, asking questions throughout the class, reviewing material at the beginning and the end of the lesson. Full inclusion occurred after teaching CIVL 304 (Su14) where the full model was employed and the mini-ExCEEd refresher (before Sp14). Dr. Bubacz visited with Dr. Welch bi-weekly to gain insight on physical models and content.

During the first semester at The Citadel Dr. Bubacz gained a better understanding of a cadets' lifestyle and the military college culture. Further adjustments to the course content were made with this type of student in mind. The Citadel cadets are very busy and their daily schedule often leaves only 3-4 hours in the evening to complete homework and study for courses. From Bubacz's experience, more learning must happen in class with additional practice occurring after class to reinforce the key concepts (i.e., daily homework). Therefore, Dr. Bubacz tried to repeat concepts frequently in class by reviewing them on the board and asking stimulating questions.

Dr. Bubacz was then exposed to evening $2+2$ students the following semester and gained a deeper understanding of this nontraditional group of students and their study habits. The evening students are transfer students who completed their core courses at community colleges and are often working full time during the day. The content and quality of core knowledge may vary from college to college, and some prior knowledge may be forgotten if taken a long time ago, and a review of basics is usually warranted.

CIVL 202 Statics was taught three semesters in a row to six sections of students: two, one and three sections respectively. During these course offerings the following changes were incorporated:

- new course content that is appropriate for both Civil and Mechanical Engineering students and included as an FE exam topic,

- new textbook,

- complete instructional materials: board notes, homework problems and solutions sets created outside of textbook to avoid copying from solution manuals

- bonus point system related to Supplemental Instruction sessions (tutoring) and reworked test problems

- in-class questioning and concept checks for bonus points for volunteers and selected students (often those who need extra credit)

- positive rapport with students created by Dr. Bubacz's enthusiasm and interest in each student and progress in the course - the results can be found in Tables 5-7 and Figure 4.

The teaching of the ExCEEd built course allowed Dr. Bubacz to fully experience the ExCEEd model in action and brought the concepts covered in the mini-ExCEEd to full view. The use of ExCEEd Teaching Workshop best practices Fall 14 and Spring 15 are clearly evident in students' assessment and comments. 
Table 5. Comparison of Faculty Questions average score from Course Evaluations.

\begin{tabular}{|c|c|c|c|}
\hline Semester since started & Course & $\begin{array}{c}\text { Average score } \\
\text { (1-5 Likert scale) }\end{array}$ & Notes \\
\hline 1 (Spring 2014) & CIVL 310 & 3.89 & $\begin{array}{c}\text { Mini-ExCEEd } \\
\text { before SP14 }\end{array}$ \\
\cline { 2 - 4 } & CIVL 202 & 3.98 & $\begin{array}{c}\text { ExCEEd Built } \\
\text { Course }\end{array}$ \\
\hline 2 (Summer 2014) & CIVL 304 & 3.74 & $\begin{array}{c}\text { Mini-ExCEEd } \\
\text { before SP15 }\end{array}$ \\
\hline 3 (Fall 2014) & CIVL 202 & 4.51 & \\
\hline 4 (Spring 2015) & CIVL 202 & 4.45 & \\
\hline
\end{tabular}

Table 6. Comparison of Faculty Questions scores from Course Evaluations.

\begin{tabular}{|c|c|c|c|c|c|}
\hline \multirow[t]{2}{*}{ Question } & \multicolumn{2}{|c|}{ Spring 2014} & Summer & Fall & Spring \\
\hline & $\begin{array}{c}\text { CIVL } \\
310 \\
\end{array}$ & $\begin{array}{l}\text { CIVL } \\
202 \\
\end{array}$ & $\begin{array}{c}\text { CIVL } \\
304 \\
\end{array}$ & $\begin{array}{c}\text { CIVL } \\
202 \\
\end{array}$ & $\begin{array}{c}\text { CIVL } \\
202 \\
\end{array}$ \\
\hline $\begin{array}{l}\text { 1. My professor displays a clear } \\
\text { understanding of course topics. }\end{array}$ & 4.4 & 4.4 & 4.3 & 4.7 & 4.6 \\
\hline $\begin{array}{l}\text { 2. My professor seems well- } \\
\text { prepared for class. }\end{array}$ & 4.1 & 4.4 & 4.1 & 4.6 & 4.6 \\
\hline $\begin{array}{l}\text { 3. My professor speaks audibly and } \\
\text { clearly. }\end{array}$ & 3.9 & 3.9 & 3.6 & 4.5 & 4.4 \\
\hline $\begin{array}{l}\text { 4. My professor displays enthusiasm } \\
\text { when teaching. }\end{array}$ & 4.1 & 4.4 & 3.7 & 4.7 & 4.5 \\
\hline $\begin{array}{l}\text { 5. My professor makes good use of } \\
\text { examples and illustrations. }\end{array}$ & 3.5 & 4.2 & 3.6 & 4.6 & 4.4 \\
\hline $\begin{array}{l}\text { 6. My professor makes effective use } \\
\text { of class time. }\end{array}$ & 3.8 & 4.1 & 3.7 & 4.5 & 4.6 \\
\hline $\begin{array}{l}\text { 7. My professor begins and ends } \\
\text { class on time. }\end{array}$ & 4.3 & 4.4 & 3.9 & 4.6 & 4.6 \\
\hline $\begin{array}{l}\text { 8. My professor is readily available } \\
\text { for consultations. }\end{array}$ & 4.3 & 3.7 & 3.9 & 4.4 & 4.5 \\
\hline $\begin{array}{l}\text { 9. My professor effectively } \\
\text { challenged me to think. }\end{array}$ & 4.3 & 4.2 & 4.2 & 4.4 & 4.5 \\
\hline $\begin{array}{l}\text { 10. My professor communicated the } \\
\text { subject matter effectively. }\end{array}$ & 3.5 & 3.6 & 3.8 & 4.4 & 4.4 \\
\hline $\begin{array}{l}\text { 11. When I have a question or } \\
\text { comment I know it will be } \\
\text { respected. }\end{array}$ & 3.9 & 4.1 & 3.2 & 4.6 & 4.5 \\
\hline $\begin{array}{l}\text { 12. I would recommend taking a } \\
\text { course taught by this professor. }\end{array}$ & 3.4 & 3.3 & 3.4 & 4.4 & 4.2 \\
\hline 13. I would enjoy taking another & 3.4 & 3.2 & 3.4 & 4.4 & 4.1 \\
\hline
\end{tabular}




\begin{tabular}{|l|l|l|l|l|l|}
\hline course from this professor. & & & & & \\
\hline $\begin{array}{l}\text { 14. I would rate my professor as an } \\
\text { excellent teacher. }\end{array}$ & 3.5 & 3.3 & 3.5 & 4.4 & 4.3 \\
\hline
\end{tabular}

SP 14 after first mini-ExCEEd, CIVL 301 70\% PowerPoint, CIVL 202 no PowerPoint. SU14, ExCEED built course. F14 after teaching with ExCEEd built course in summer and SP 15 after attending second mini-ExCEEd.

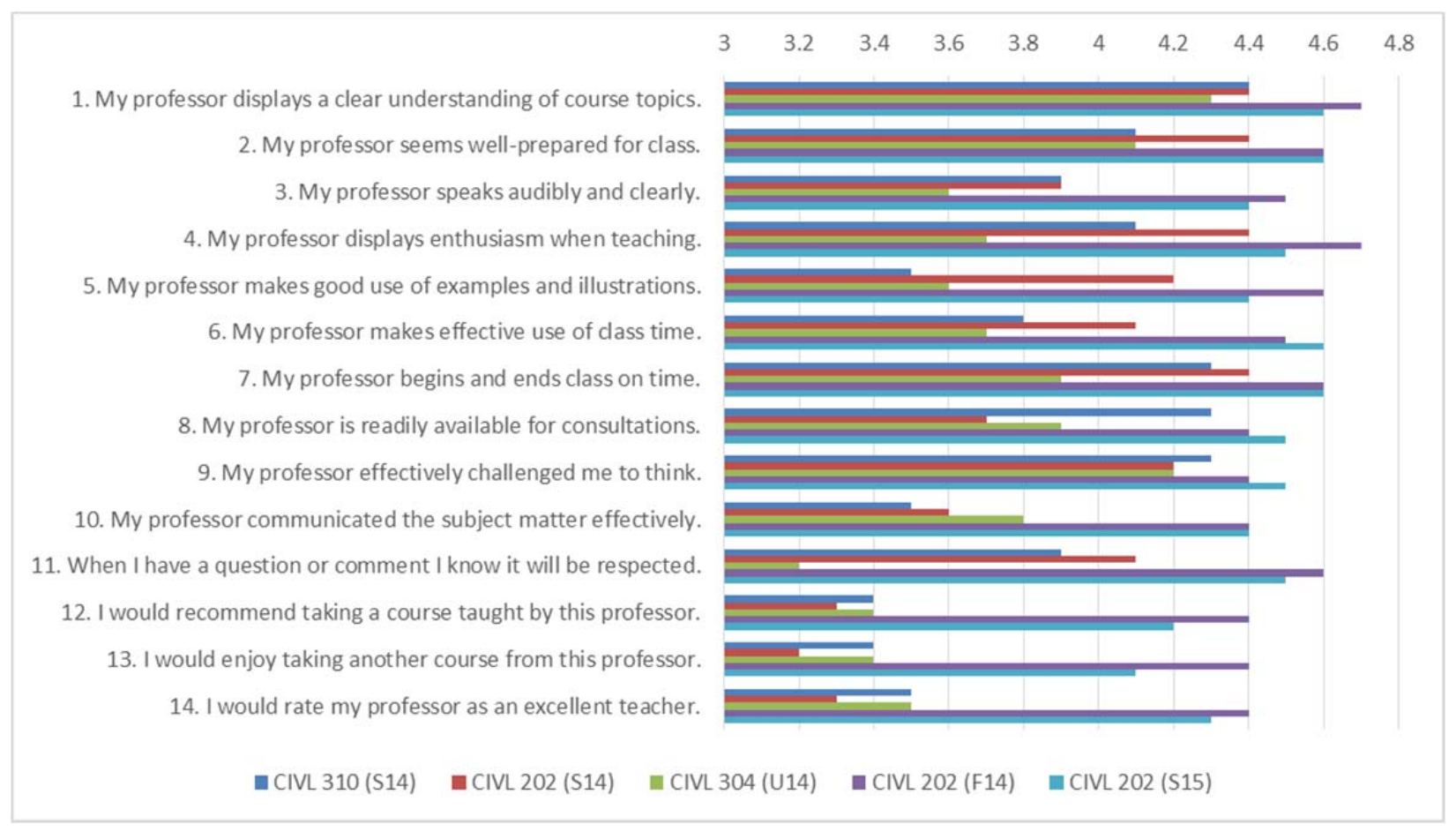

Figure 4. Comparison of Student Evaluations over multiple semesters

\section{Table 7: Student comments from evaluation}

\begin{tabular}{|c|c|}
\hline Class (Semester) & Comment \\
\hline $\begin{array}{l}\text { CIVL } 310 \text { (Spring } \\
\text { 2014, After Mini- } \\
\text { ExCEEd, 70\% } \\
\text { PowerPoint) }\end{array}$ & $\begin{array}{l}\text { "More hands on teaching will help those who have a hard time } \\
\text { visualizing } 4 d \text { methods. Try asking questions to specific people instead } \\
\text { of letting the same people who get the material answer the questions." }\end{array}$ \\
\hline $\begin{array}{l}\text { CIVL } 202 \text { (Spring } \\
\text { 2014) }\end{array}$ & $\begin{array}{l}\text { "I would recommend more demonstrative props to aid spatial } \\
\text { comprehension of the material." }\end{array}$ \\
\hline $\begin{array}{l}\text { CIVL } 304 \text { (Summer } \\
\text { 2014, ExCEEd built } \\
\text { Course) }\end{array}$ & $\begin{array}{l}\text { "The teacher needs to model class questions closer to test questions ..." } \\
\text { "Several visual aids brought in to explain complex material." }\end{array}$ \\
\hline $\begin{array}{l}\text { CIVL } 202 \text { (Fall } \\
\text { 2014, after teaching } \\
\text { ExCEEd built } \\
\text { course) }\end{array}$ & $\begin{array}{l}\text { "The professor was awesome in the respect of always being available for } \\
\text { help and better understanding of subject matter." }\end{array}$ \\
\hline
\end{tabular}




\begin{tabular}{|l|l|}
\hline CIVL 202 (Spring & "Bubacz is a great professor that involves the class in the learning \\
2015, after attending & process, effectively challenging us to think on the spot, but also pointing \\
second mini- & us in the right direction if we are having trouble. Easily approachable for \\
ExCEEd) & help outside of class as well."
\end{tabular}

Dr. Skenes is a tenure-track assistant professor, ME, who joined The Citadel's School of Engineering at the start of the fall 2014 semester. One of Dr. Skenes' first teaching assignments was Engineering Administration (CIVL 314). CIVL 314 has been a part of the engineering curriculum for some time, and has a well-established course layout which the assistant professor obtained from another faculty member concurrently teaching the course.

The structure of CIVL 314 was very heavily PowerPoint-based, with slides for each lecture. A summary of the course structure can be described as $85 \%$ PowerPoint and $15 \%$ whiteboard examples. The slide sets contained lecture notes as well as example problems and answers. In an attempt to correct what was perceived as an overuse of PowerPoint, Dr. Skenes removed examples from the slides and committed to working through problems on the whiteboard instead. The faculty member was not familiar with the ExCEEd model of teaching at this time.

Mechanics of Materials (CIVL 304) was assigned to Dr. Skenes for the spring 2015 semester. Prior to the start of the semester, Dr. Skenes attended a mini-ExCEEd teaching workshop. Furthermore, Dr. Welch who taught the ExCEEd workshop provided complete course content from previous semesters of CIVL 304. This course content included a syllabus, lesson notes, homework, exams, design problems, and a study guide. The course was thus predominantly structured around ExCEEd tenets, and could be described as 98\% whiteboard notes and 2\% PowerPoint. While the senior faculty member was available for questions pertaining to the class throughout the semester, the junior faculty member was encouraged to construct the class independently using the previous semesters as a blueprint. Dr. Bubacz (discussed above) who taught the course summer 2014 had her office next door and was available for content and teaching pedagogical questions (mentoring being passed on).

Students evaluate each professor on a 5-point Likert scale using a standard survey provided by the school at the end of each semester. Evaluations of CIVL 314 and CIVL 304 and Dr. Skenes' teaching style in each class are provided below. Table 8 lists the survey questions asked, while Figure 5 displays the results.

The student evaluations rated Dr. Skenes higher in 11 of 12 categories when teaching CIVL 304 than CIVL 314, while the $12^{\text {th }}$ category ("My professor communicated the subject material effectively") held steady. This resulted in an average score increase from 4.38 to 4.63 . Furthermore, Questions 1 and 5 indicate performance below the average of The Citadel School of Engineering in CIVL 314 which was then improved to above average in CIVL 304. Question 2 ("Many methods are used to involve me in learning") remained the lowest score and slightly below the School of Engineering average, but still increased by 8\%. The increase is likely due to the use of physical models and/or videos and more interactive classroom activities. As Dr. Skenes' understanding of the different learning styles increases, this score is expected to rise to meet the institution average. 
Table 8: Questions on student evaluations

\begin{tabular}{|l|l|}
\hline Q1 & I learned a lot in this course. \\
\hline Q2 & $\begin{array}{l}\text { In this course many methods are used to involve me in } \\
\text { learning. }\end{array}$ \\
\hline Q3 & My professor displays a clear understanding of course topics. \\
\hline Q4 & My professor seems well-prepared for class. \\
\hline Q5 & My professor displays enthusiasm when teaching. \\
\hline Q6 & My professor makes good use of examples and illustrations. \\
\hline Q7 & My professor makes effective use of class time. \\
\hline Q8 & My professor effectively challenged me to think. \\
\hline Q9 & My professor communicated the subject matter effectively. \\
\hline Q10 & $\begin{array}{l}\text { When I have a question or comment I know it will be } \\
\text { respected. }\end{array}$ \\
\hline Q11 & I would recommend taking a course taught by this professor. \\
\hline Q12 & I would enjoy taking another course from this professor. \\
\hline
\end{tabular}

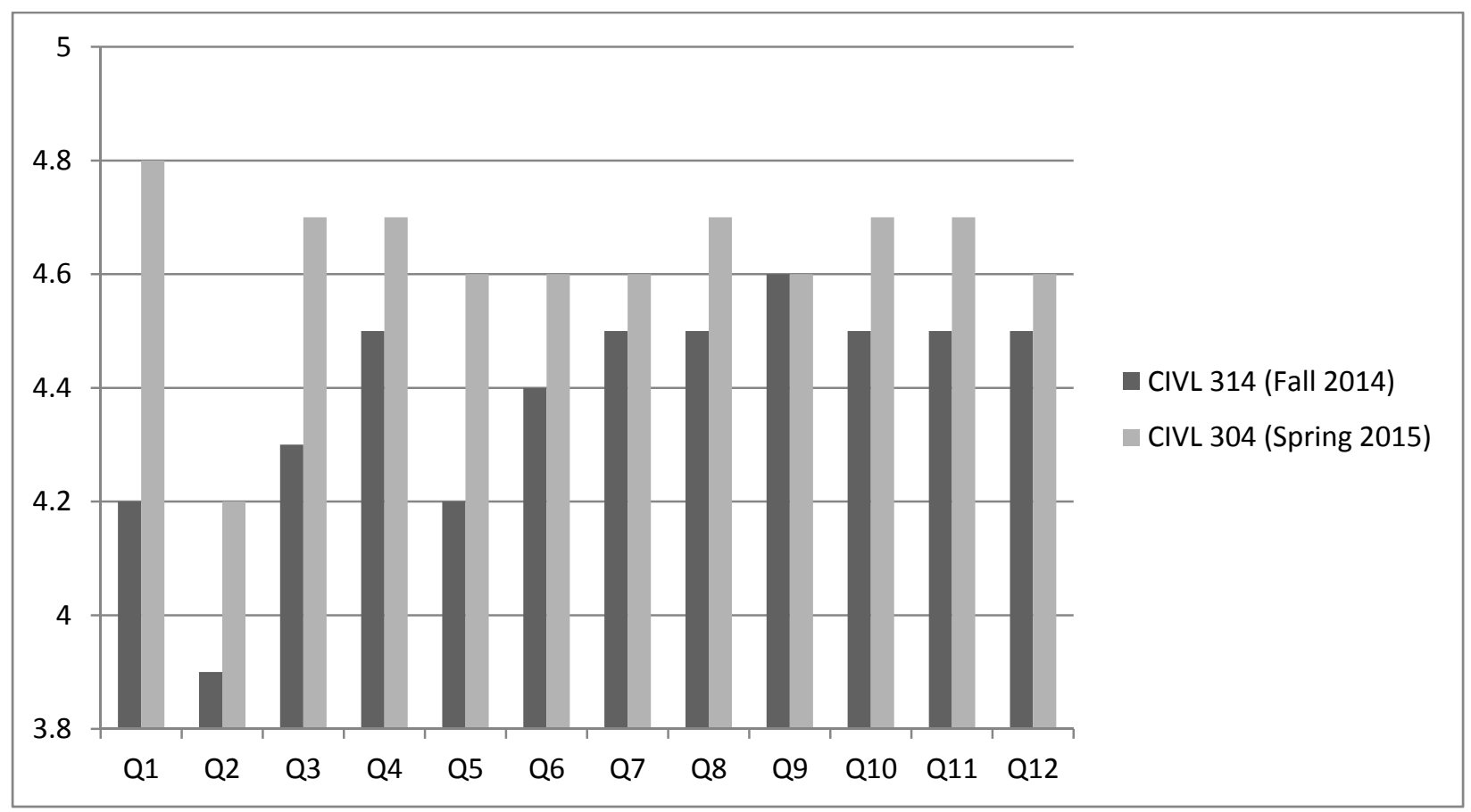

Figure 5: Comparison of student evaluations in CIVL 314 and CIVL 304

Students were also invited to submit positive comments and/or constructive criticism on the faculty member's teaching style. Representative comments from both classes are listed below in Table 9. 
Table 9: Student comments from evaluation

\begin{tabular}{|l|l|}
\hline Class (Semester) & Comment \\
\hline $\begin{array}{l}\text { CIVL 314 (Fall } \\
\text { 2014) }\end{array}$ & $\begin{array}{l}\text { "[There] needs to be more [than] just reading the slide show and doing a } \\
\text { few examples in class. The students should be more involved in the } \\
\text { class..." }\end{array}$ \\
\hline $\begin{array}{l}\text { CIVL 314 (Fall } \\
\text { 2014) }\end{array}$ & $\begin{array}{l}\text { "[The professor] would often break off into tangents that consumed too } \\
\text { much class time." }\end{array}$ \\
\hline $\begin{array}{l}\text { CIVL 304 (Spring } \\
\text { 2015) }\end{array}$ & $\begin{array}{l}\text { "Loved the material, interesting, and you can see where [it] will apply in } \\
\text { real life." }\end{array}$ \\
\hline $\begin{array}{l}\text { CIVL 304 (Spring } \\
\text { 2015) }\end{array}$ & "The upbeat professor and the way he presented the material." \\
\hline
\end{tabular}

Figure 5 and Table 9 indicate that CIVL 304 was a more effective course and was more wellreceived by students. The authors believe this to be the effect of several changes made in teaching style and course structure between the two classes. First, the ExCEEd model encourages structured organization based on learning objectives. This objective-based structure was not present in CIVL 314, but Dr. Skenes made a concerted effort to create objective-oriented lessons in CIVL 304 based on the material provided by Dr. Welch. Second, the lecture model was changed to be more varied and interactive. This increased degree of interaction included physical models and a higher degree of interaction between the professor and the students. These changes were put in place to address the concerns voiced by students after CIVL 314, and were greatly assisted by the ExCEEd workshop and the course materials provided prior to the Spring 2015 semester. Figure 5 and Table 9 indicate that students responded well to the changes in instruction style and ExCEEd model built course.

In the Fall of 2015, Dr. Mays (CE) who teaches Dynamics (CIVL 301) using direct instruction with a track record of very high student evaluation results for this course (4.8/5.0 average for 10 times taught) and three national teaching awards was mentored by Dr. Welch using the ExCEEd model. Previous results of student evaluation surveys (in CIVL 301) for Dr. Mays have shown that the high marks received have been directly related to the faculty member's excellent rapport with the students, unquestioned expertise of the subject matter, and practical experience outside the classroom that is brought into the class on an almost daily basis. On the contrary, student evaluations have not typically mentioned the effective use of the ExCEEd teaching model principal characteristics described earlier in this paper and senior faculty teaching evaluations of Dr. Mays have noted the possible overuse of PowerPoint in course lectures as well as other improvement areas when using direct instruction. As part of this study, Dr. Welch shared his entire Mechanics of Materials (CIVL 304) course content (lesson notes, homework, exams, design problems, syllabus, and study guide) that is built entirely on the ExCEEd model with Dr. Mays so that both sections could be taught by the two CE, senior and mid-term, faculty members using the same notes, assignments, and exams on the exact same schedule. The two met usually weekly to discuss content delivery, homework solutions and grading or exam length.

Dr. Mays taught both CIVL 301 and CIVL 304 in the Fall of 2015 as part of this study (Table 10). The senior faculty member taught only CIVL 304. CIVL 301 was taught in the same manner that it has been taught by Dr. Mays the previous 10 times. The basic makeup of the 
CIVL 301 course can be described as follows: 80 percent PowerPoint based (20 percent whiteboard); partially graded homework due every two weeks; two exams (midterm and final); short chapter based learning objectives; no fixed "per class" schedule (i.e., all material is covered but each chapter is completed whenever it is completed). The basic makeup of the ExCEEd developed CIVL 304 course developed by Dr. Welch can be described as follows: 2 percent PowerPoint based (98 percent whiteboard); fully graded homework due every class; four exams (three mid-term and one final); very detailed chapter based learning objectives tied to each assessed item; fixed "per class" schedule clearly outlined on the course syllabus.

Table 10. Comparison of CIVL 301 and CIVL 304

\begin{tabular}{|l|l|l|}
\hline Item & CIVL 301 & CIVL304 \\
\hline PowerPoint & $80 \%$ & $2 \%$ \\
\hline Whiteboard Use & $20 \%$ & $98 \%$ \\
\hline Graded Homework & $\begin{array}{l}\text { Partially graded, every two } \\
\text { weeks }\end{array}$ & Fully Graded, daily \\
\hline Mid-Term exams & One & Three \\
\hline Final Exam & Covered last portion of course & Comprehensive \\
\hline Learning objectives & $\begin{array}{l}\text { Chapter completed when } \\
\text { completed }\end{array}$ & $\begin{array}{l}\text { Detailed chapter based per } \\
\text { class schedule }\end{array}$ \\
\hline
\end{tabular}

Figure 6 presents the results of a student survey given at the end of the Fall 2015 semester in addition to the school-wide survey where the results were nearly identical for Dr. Welch and Dr. Mays. The statements the students responded to are provided in the figure and they were asked to respond using the following indicators: 1 - Strongly Agree; 2 - Agree; 3 - Not Sure; 4 Disagree; 5 - Strongly Disagree. The questions were purposely selected by the faculty performing this study to restate the previously discussed characteristics of the ExCEEd model using language more familiar to college students. The results of the survey were very clear. In all areas (except for frequency of homework) students preferred the ExCEEd model course (CIVL 304) over CIVL 301. Since all students had Dr. Mays for CIVL 301 and half the students had Dr. Mays and half of the students had Dr. Welch for CIVL 304, the results were separated by CIVL 304 instructor (resulting figure not shown here) and found to be nearly identical. Due to other potential issues, the following three open-ended follow up questions were also asked on the survey:

1. Which class do you feel like you were more prepared for each day?

2. Do you feel like this questionnaire is a fair comparison of the two teaching styles?

3. Are you certain that the fact that the topics in the two courses are very different does not significantly impact your opinions above?

75\% of all students indicated that they were more prepared each day for CIVL 304 than CIVL 301. Many of those stated that it was the daily homework which kept them prepared. This is very interesting since the frequency of homework was their only complaint with CIVL 304. Review of the comments suggest that the $75 \%$ may have even been higher if student comments such as "I was unprepared for CIVL 304 on several cases since I did not finish the daily homework assignment” are thrown out. The student understanding of "prepared” led some 
students to conclude that they were more prepared for CIVL 301 than CIVL 304. 90\% of all students felt like the survey was a fair comparison of the teaching style used in the classroom and $82 \%$ of all students felt that the course topics being different had no significant impact on their opinions stated on the survey. The official course evaluation completed by the students in December 2015 provided similar feedback to Dr. Mays. The numerical evaluations for the two courses were statistically similar and high for both classes. However, personal, anonymous, comments did indicate a possible overuse of PowerPoint (in CIVL 301) and the lack of various methods used to address different learning styles (in CIVL 301) that is naturally part of the CIVL 304 ExCEEd format.

\section{Data Assessment}

There have been a number of studies looking at teaching workshops, teaching seminars, teaching and learning centers, outstanding teacher qualities, and teaching mentors. ${ }^{1,5,9-12}$ Each study provides best practices or compendiums as guidelines for how a teacher can improve and move toward Lowman's exemplar status ${ }^{5}$. However, none have simply provided a pedagogically designed course to mold the actions of a teacher in the current and motivate them to adjust their practices in future courses.

Kaitlin Marley, lecturer, who was already a good teacher with strong student evaluations, began to fully understand all components of a well-crafted course that assist each student to learn while ensuring the content is covered within the semester. The experience solidified her desire to complete a $\mathrm{PhD}$ and become an assistant professor.

Dr. Bubacz, ME associate professor, performed as well as past courses she had taught before even when teaching the ExCEEd built course for the first time and it being taught in the evening during a shortened summer session. More importantly, experiencing an ExCEEd built course (applying all pedagogical aspects within the ExCEEd model) first hand highlighted the ExCEEd Teaching Model seminar content which resulted in dramatic student evaluation scores the next offering of a previously taught course. The same results are seen in the offerings of other ME courses over the same time period when ME courses were being built and taught for the first time (program started in fall 2014).

Dr. Skenes, ME assistant professor, experienced incredible student evaluations (8\% increase) the next semester by simply using an ExCEEd teaching model built course after a mini-ExCEEd prior to the semester. Similar results are observed in the offerings of ME courses being built and offered for the first time (program started in fall 2014).

Dr. Mays, now CE full professor, who was teaching the same sub-set of students during the same semester in a course he had taught ten previous times observed similar student evaluations and dramatic input through a separate survey of student perceptions and grades completed at the end of the semester. The results of this survey were so convincing that Dr. Mays has begun to convert all future courses using the ExCEEd Teaching Model. Even though he has consistently received some of the highest student evaluations within his department (a great teacher already), the survey results pointed to a movement of the learning needle for his students if he adjusted his teaching style and content presentation based on the ExCEEd model. 


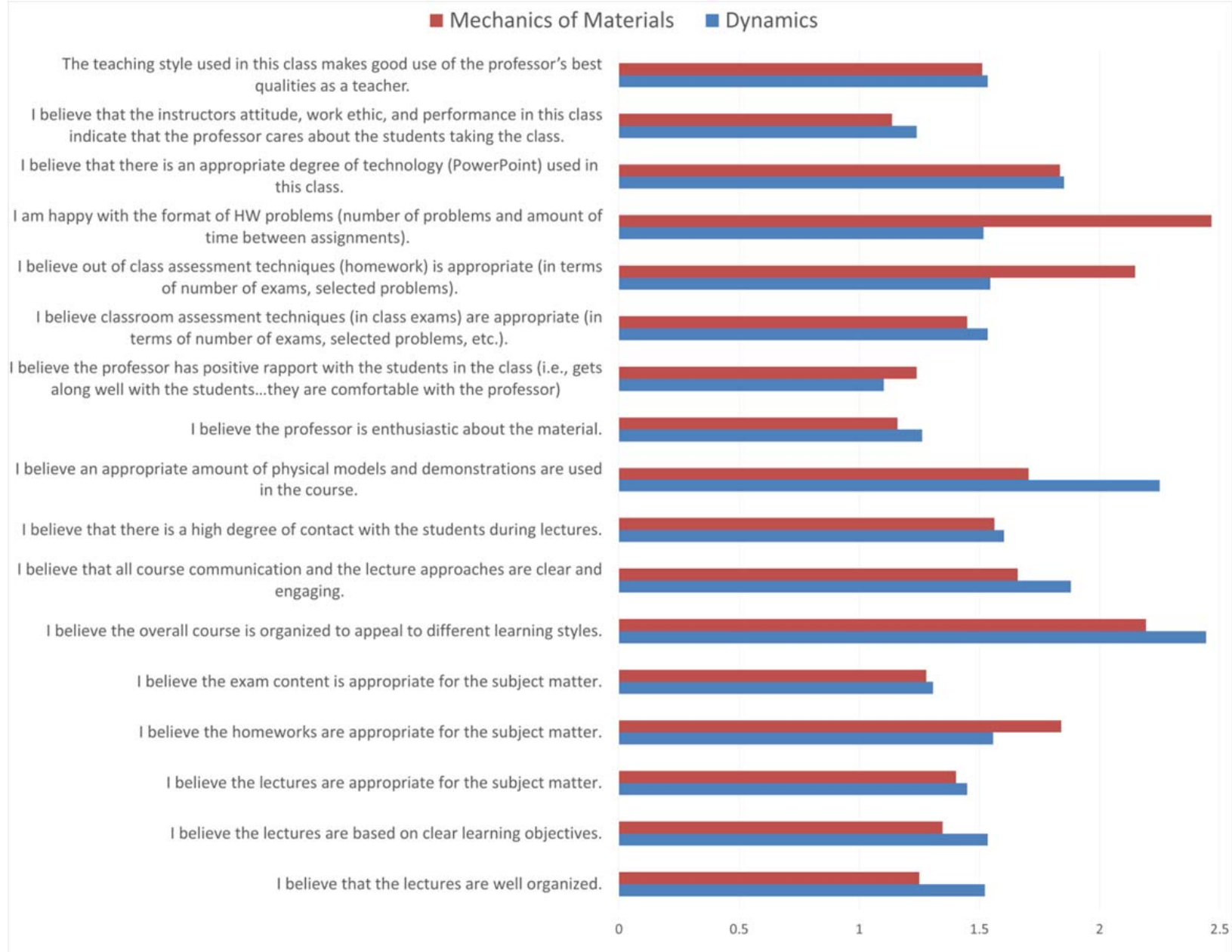

Figure 6. End of course student survey results for students taking both CIVL 301 and CIVL 304

Each faculty member was at a different level of experience and rank in their career and the use of a pedagogically built course using the ExCEEd Teaching Model displayed immediate positive results during that semester and successive semesters. The use of an ExCEEd built course allowed the content seen in the mini-ExCEEd seminars to be experienced firsthand by executing the prepared course and the positive results felt through students observed learning and student perceptions delivered through end-of-course evaluations. This active content engagement is powerful in comparison to attending and hoping faculty take the time to adjust their future courses, usually one small change at a time, based on the best practices that are presented in a teaching workshop or seminar. This methodology is similar to what faculty try to accomplish through in-class examples followed by homework with multiple opportunities to practice the presented and practices skills in class. Teaching the course built around the ExCEEd model has the faculty member fully experiencing the model and seeing the impact through the enhanced student learning as well as student evaluations.

Many programs around the country simply assign a (new) faculty to a course and provide a syllabus and sometimes an associated textbook. If the best teachers shared their pedagogically 
built courses with other faculty (new and mature) who have learned about best practices, rapid improvements in teaching might be possible and might lead to improvements in other courses taught by these same faculty. Unfortunately, many faculty feel their course is their own intellectual property that cannot be shared. In fact, most have built their courses while being employed by the university, so sharing should not be seen as an infringement on intellectual property. Additionally, senior faculty leadership should relish the role of mentoring other faculty to improve teaching which results in better retention and better prepared students for follow-on courses and the work place. This paper demonstrates how a pedagogically built course (built using the ExCEEd teaching model) that is simply shared with other faculty can dramatically improve the quality of teaching in the current as well as future semesters. Exemplars happily share course content with new faculty when teaching for the first time. Just like their students, they teach/guide all to reach their potential.

\section{Future Research}

The faculty are studying the time it takes to convert their other courses to fully embrace the ExCEEd Teaching model and the impact their ExCEEd Teaching Model based courses will have on other faculty when they share their built courses. A refinement of the student end-of-course assessment will allow a deeper dive into what portions of the ExCEEd model have the greatest and most rapid impact on student learning and perceptions about the course, the teacher, and learning.

\section{References}

1. Estes, A.C., Welch, R.W., Ressler, S.J, Dennis, N., Larson, D., Considine, C., Nilsson, T., O’Brien, J., Lenox, T., ExCEEd Teaching Workshop: Tenth Year Anniversary, Proceedings of the 2008 American Society for Engineering Education Annual Conference \& Exposition

2. Angelo, T. A., A Teacher's Dozen, AAHE Bulletin, April, (1993).

3. Bain, K., What the best College Teachers Do, April 2004

4. Chickering, A. W. and Z. F. Gamson, Seven Principles for Good Practice in Undergraduate Education, AAHE Bulletin, March, (1987).

5. Lowman, J., Mastering the Techniques of Teaching, Jossey-Bass Publishers, (1995).

6. McKeachie, W. J., Teaching Tips, Strategies, Research, and Theory for College and University Teachers, 10th ed, Boston, Houghton Mifflin Company, (1999).

7. Nilson, L., Teaching at Its Best: A Research-Based Resource for College Instructors, Jossy-Bass, May 2010, Chapter 1: Understanding How Your Students Learn

8. Wankat, P., and F. Oreovicz, Teaching Engineering, New York, McGraw-Hill, (1993).

9. Coso, A., Sekayi, D., Exploring the role of institutional climate in preparing engineering doctoral students for academic careers, Proceedings of the 2015 American Society for Engineering Education Annual Conference \& Exposition

10. Grinter, et.al, The Grinter Report, Journal of Engineering Education, pp. 74-94, January 1994

11. Dennis, N., Clausen, E., Clinical Faculty Development Program, 2055 ASEE Zone III Conference Proceedings

12. Bedekar, V., Lee, J., Spearot, D., Learning How to Learn and Teach: Mentor and Mentee Team, Proceedings of the 2013 American Society for Engineering Education Annual Conference \& Exposition 